10. Akram M., Shahid M., Khan A. U. Etiology and antibiotic resistance patterns of community-acquired urinary tract infections in J N M C Hospital Aligarh, India Ann. Clin. Microbiol. Antimicrob. 2007;4(6).

11. Hoberman A., Charron M., Hickey R. W. et al. Imaging

MONITORING SURVEY OF ANTIBIOTIC SENSITIVITY IN CHILD URINARY SYSTEM INFECTIOUS AGENTS (EXPERIENCE IN STAVROPOL)

MEDVEDEVA A. N., KALMYKOVA A. S.

The population subject to the study included 220 children aged 1 month - 5 years, with acute community acquired infections of the upper and lower urinary tract. As the data obtained showed, the major agents causing community acquired UTI in the first 5 years of age were bacteria belonging to the Enterobacteriaceae family, E. coli predominantly. The major features in the structure of the agents responsible for UTI development in the children of Stavropol (Russia) were higher detection frequency of Str.faecalis, which was the second most common in all the groups examined, while the children aged c 3-5 had it 1.8-2.9 times as often.

In view of the leading etiological significance of Enterobacteriaceae as well as taking into account the obtained data on the pathogens susceptibility towards antibiotics, Amoxiclav, Cefotaxime, Cefoperazone, Ceftazidime, Cefepime, and Meropenem make a reasonable choice as empiric therapy for treating community acquired UTI in children aged up to 5 . The penicillin antibiotics (Ampicillin, Amoxicillin, Oxacillin) and Laevomycetin should not be administered for empiric treatment due to the high-level resistance Enterobacteriaceae revealed towards them.

Key words: children, urinary tract infection, sensitivity, antibiotic drugs studies after a first febrile urinary tract infection in young children. N. Engl. J. Med. 2003;3(348):195-202.

12. Chakupurakal R., Ahmed M., Sobithadevi D. N., Chinnappan S., Reynolds T. Urinary tract pathogens and resistance pattern. J. Clin. Pathol. 2010;7(63):652-654.

\section{МОНИТОРИНГ ЧУВСТВИТЕАЬНОСТИ ВОЗБУАИТЕАЕЙ ИНФЕКЦИЙ МОЧЕВОЙ СИСТЕМЫ У АЕТЕЙ Г. СТАВРОПОАЯ}

A. H. MEABEAEBA, A. C. KA^MЫKOBA

Было обследовано 220 детей в возрасте от 1 месяца до 5 лет с острыми внебольничными инфекциями верхних и нижних мочевых путей. Установлено, что основными возбудителями внебольничных ИМС у детей первых 5 лет жизни являются представители семейства Enterobacteriaceae, главным образом E. coli. Основными особенностями структуры возбудителей ИМС детей г. Ставрополя являлось более частое выделение Str. faecalis, занимавшего второе место в структуре во всех группах, причем у детей с 3 до 5 лет он обнаруживался в 1,8-2,9 раза чаще.

Учитывая ведущую этиологическую роль Enterobacteriaceae и полученные результаты чувствительности, для эмпирической терапии внебольничной ИМС у детей до 5 лет целесообразно использовать амоксиклав, цефотаксим, цефоперазон, цефтазидим, цефепим, меропенем. Антибиотики из группы пенициллинов (ампициллин, амоксициллин, оксациллин) и левомицетин не следует назначать для эмпирической терапии в связи с высоким уровнем резистентности к ним Enterobacteriaceae.

Ключевые слова: дети, инфекция мочевой системы, чувствительность, антибиотики

\title{
DURATION OF LATENT PERIOD AND IRON DEFICIENCY DEVELOPMENT IN CHILDREN WITH CELIAC DISEASE
}

\author{
Klimov L. Ya. ${ }^{1}$, Kuryaninova V. A. ${ }^{1,2}$, Stoyan M. V. ${ }^{1,2}$, Asaturova D. V. ${ }^{1}$, \\ Gerasimenko E. S. ${ }^{1}$, Daguzhieva M. D. ${ }^{1}$
}

\section{Stavropol State Medical University, Russian Federation \\ 2 Philippsky Child Clinical Hospital, Stavropol, Russian Federation}

Klimov Leonid, MD, Associate Professor, Head of Faculty Pediatrics Department, Stavropol State Medical University tel.: 89289630261; e-mail: klimov_leo@mail.ru

Kuryaninova Victoria, Assistant of Propaedeutics of Children's Diseases Department, Stavropol State Medical University; tel.: 89282938069; e-mail: vichkak@mail.ru

Stoyan Marina, Assistant of Faculty Pediatrics Department Stavropol State Medical University;

tel.: 89282447990; e-mail: marina-stoyan@mail.ru

Asaturova Dayana, student of Pediatric Faculty, Stavropol State Medical University;

tel.: 89187914671; e-mail: miss.asaturova@mail.ru;

Gerasimenko Elena, Postgraduate student of Faculty Pediatrics Department, Stavropol State Medical University; tel.: 89886785715; e-mail: Drelena555@yandex.ru eliac disease in children is mostly associated with the development of a typical malabsorption syndrome, the neviitable parts of the latter being polyhypomicroelementosis and polyhypovitaminosis [3, 4, 15]. Obviously, the age at the onset of the disease typically depending on the time gluten was introduced into the diet, as well as the period prior to the verification of diagnosis (i.e. latent period), do have an impact on the patient body's iron supply [8]. In view of the high lability and vulnerability typical of iron metabolism in children, any disturbances in its 
intestinal absorption may be fast in leading to iron deficiency (ID) $[2,6,11]$.

On the other hand, iron deficiency anemia (IDA), if continuous and refractory to the conventional iron therapy treatments, especially when in children and adolescents, is an absolute indication for the patients to be examined for celiac disease because this may be the only clinical symptom of the atypical form of this disease. As some researchers claim, celiac disease is diagnosed in at least 5-9\% of cases with IDA [3, 4, 5, 7, 10, 14].

Mention to be made here that in case of a prolonged course of celiac disease some patients develop anemia of chronic disease (ACD), which is due to the detrimental effect that the main haematopoetic organs and activity of transport proteins (transferrin, ferritin) suffer from proinflammatory cytokines (IL-6, TNF- $\alpha$, etc.), whose increased levels could be seen through the active disease period $[1,5,7,9,12,13]$.

The purpose of this work is to analyze the relationship between the duration of undiagnosed celiac disease and the development of ID in children and adolescents.

Material and Methods. The study embraced case records for 126 children aged 9 months to 15 years, going through an acute stage of celiac disease, and who went through examination at the G. K. Philippsky Clinical Hospital Gastroenterology Department (Stavropol, Russia) in 1996-2013. $67(53.2 \%)$ of the examinees were boys the rest of them - 59 (46.8 \%) - girls. The diagnosis was given based on the clinical, serological and morphological criteria ESPGHAN, while the physical measures (body length, body weight, body mass index (BMI)) were assessed following the AnthroPlus-2011 programme.

The ID types (IDA and latent iron deficiency / LID) were verified in accordance with generally accepted criteria based on the data of clinical bloodwork, serum iron (SI) blood test, total iron binding capacity (TIBC), and ferritin blood test $[2,6]$.

In $46(36.5 \%)$ cases the bloodwork test was done using an automatic analyzer, which allows detecting these patients' indices pertaining to erythroid cells from peripheral blood $(\mathrm{MCV}, \mathrm{MCH}$, $\mathrm{MCHC}, \mathrm{RDW}$ ), which reflect the qualitative features of erythropoiesis [2, 6].

The patients were divided into 3 groups - Group 1 included 37 (29.4\%) children with IDA; Group 2 - $37(29 / 4 \%)$ patients with LID, and group 3 - 52 (41.2 \%) children with no laboratory signs of ID. In Group 1, grade I anemia (Hb 90-110/120 g/I) was found in 24 (64.9\%) children; grade II anemia ( $\mathrm{Hb}$ 70-90 g/l) was detected in 12 (32.4 \%) children, while grade III anemia ( $\mathrm{Hb}$ below $70 \mathrm{~g} / \mathrm{l}$ ) was diagnosed in 1 (2.7\%) child only.

The data were processed with statistical methods involving the software package ATTESTAT. The quantitative characteristics are presented as mean \pm mean square (or standard) deviation. The extent of the differences was assessed with the
Student t-test for unrelated samples. The significance of the differences for the nonparametric indices was calculated by the Pearson $\left(\chi^{2}\right)$ method, while the differences were considered significant when $p<0.05$.

Results and Discussion. An analysis of the patients' gender showed that IDA was found (Group I) in 20 (54.1\%) girls and 17 (45.9\%) boys; LID had 15 (40.5\%) girls and 22 (59.5\%) boys, while those with no ID accounted for 24 $(46.2 \%)$ of girls and $28(53.8 \%)$ of boys ( $>0.05)$. In general, the ID occurrence was not significantly dependent on the gender of children with celiac disease, whereas in boys it was 39 (58.2 \%) cases, and in girls - 35 (59.3\%).

Rather than the gender, much more important in relation to ID development were the anamnestic data (the age at which the symptoms first manifested; the duration of the latent period; the age at which the diagnosis was given).

Table 1 offers data on the verification age and the antecedent latency of celiac disease in children with ID and without that.

\section{Table 1 \\ Anamnestic features of the children depending on the presence / absence of iron deficiency through} verification of celiac disease

\begin{tabular}{|c|c|c|c|c|}
\hline \multirow{2}{*}{$\begin{array}{c}\text { Anamnestic } \\
\text { data }\end{array}$} & \multicolumn{3}{|c|}{ Patients with celiac disease } & \multirow{2}{*}{$\begin{array}{l}\text { Total. } \\
\mathrm{n}=126\end{array}$} \\
\hline & $\begin{array}{l}\text { IDA. } \\
n=37\end{array}$ & $\begin{array}{c}\text { LID. } \\
n=37\end{array}$ & $\begin{array}{c}\text { ID. } \\
n=52\end{array}$ & \\
\hline \multicolumn{5}{|c|}{ Age at verification of diagnosis } \\
\hline Under & $\begin{array}{c}4 \\
(40.0 \%)\end{array}$ & $\begin{array}{c}5 \\
(50.0 \%)\end{array}$ & $\begin{array}{c}1 \\
(10.0 \%)\end{array}$ & $\begin{array}{c}10 \\
(100.0 \%)\end{array}$ \\
\hline $1-3$ & $\begin{array}{c}15 \\
(23.1 \%)\end{array}$ & $\begin{array}{c}22 \\
(33.8 \%)\end{array}$ & $\begin{array}{c}28 \\
(43.1 \%)\end{array}$ & $\begin{array}{c}65 \\
(100.0 \%)\end{array}$ \\
\hline $3-7$ & $\begin{array}{c}8 \\
(25.8 \%) \\
\end{array}$ & $\begin{array}{c}6 \\
(19.4 \%) \\
\end{array}$ & $\begin{array}{c}17 \\
(54.8 \%)\end{array}$ & $\begin{array}{c}31 \\
(100.0 \%) \\
\end{array}$ \\
\hline $7-11$ & $\begin{array}{c}4 \\
(57.1 \%)\end{array}$ & $\begin{array}{c}1 \\
(14.3 \%)\end{array}$ & $\begin{array}{c}2 \\
(28.6 \%)\end{array}$ & $\begin{array}{c}7 \\
(100.0 \%)\end{array}$ \\
\hline Abov & $\begin{array}{c}6 \\
(46.1 \%)\end{array}$ & $\begin{array}{c}3 \\
(23.1 \%)\end{array}$ & $\begin{array}{c}4 \\
(30.8 \%)\end{array}$ & $\begin{array}{c}13 \\
(100.0 \%)\end{array}$ \\
\hline Mec & $64.4 \pm 9.0$ & $40.6 \pm 6.9$ & $43.8 \pm 5.0$ & \\
\hline \multicolumn{5}{|c|}{ Latent period. duration } \\
\hline ding & $\begin{array}{c}19 \\
(25.0 \%) \\
\end{array}$ & $\begin{array}{c}24 \\
(31.6 \%) \\
\end{array}$ & $\begin{array}{c}33 \\
(43.4 \%) \\
\end{array}$ & $\begin{array}{c}76 \\
(100.0 \%)\end{array}$ \\
\hline $24-60$ months & $\begin{array}{c}5 \\
(17.2 \%) \\
\end{array}$ & $\begin{array}{c}10 \\
(34.5 \%)\end{array}$ & $\begin{array}{c}14 \\
(48.3 \%)\end{array}$ & $\begin{array}{c}29 \\
(100.0 \%) \\
\end{array}$ \\
\hline \begin{tabular}{|l|} 
Over 60 \\
months
\end{tabular} & $\begin{array}{c}13 \\
(61.9 \%)\end{array}$ & $\begin{array}{c}3 \\
(14.3 \%)\end{array}$ & $\begin{array}{c}5 \\
(23.8 \%)\end{array}$ & $\begin{array}{c}21 \\
(100.0 \%)\end{array}$ \\
\hline $\begin{array}{l}\text { Mean } \\
\text { duration. } \\
\text { months }\end{array}$ & $45.1 \pm 7.9$ & $23.8 \pm 4.1$ & $28.7 \pm 3.6$ & \\
\hline
\end{tabular}

An analysis of the data presented in Table 1 shows an important pattern: the average age for verification of the celiac disease in patients with IDA is 1.58 times as high $(p<0.05)$ if compared to children with LID, and is 1.47 times as high $(p<0.05)$ compared to children with no ID. The general prevalence of ID conjoint with celiac disease depending on the terms of its verification shows an extremely specific dynamics. Among those 
patients in their first year of life, the occurrence of ID was $90 \%$, this to be explained with high tension and vulnerability of iron metabolism in them. Later on, in the preschool and school years the ID occurrence index lays around $50 \%$, being almost equally spread between IDA and LID. However at the age above 7 along with the disease duration going up, the ID rate goes up to $70.0 \%$ again, while schoolers reveal IDA dominating the ID pattern (80,0\% of the cases).

Putting the ID occurrence against the duration of the latent period could send us facing a similar regularity. In children whose disease course has been not above 24 months the frequency of ID is $56.6 \%$, while in those with a disease course of over 60 months ( 5 years) it goes up by 1.35 times $(76.2 \%)$. Besides in the ID pattern in children with the disease present for more than 5 years, IDA accounts for $81.3 \%$ while LID is diagnosed more often in the initial years of the disease $(p<0.01)$.

It is obvious that in the first year of life the ID occurrence rate, which in children with celiac disease reaches up to $90 \%$, is due to a high need for iron experienced by the body, as well as due to an increased level of sensitivity to even slightest disturbances in its absorption; in the course of time this all is followed by a relative stability acquired by the nutritive status, which comes along with a reduction in the number of patients demonstrating the symptoms and laboratory data typical of ID. Further prolongation of the latent period preserving even a subclinical course of the malabsorption syndrome shall have an extremely negative impact on the deposited iron, which causes a significant ID occurrence increase in patients at their preschool and preschool age.

Table 2 offers a view on an analysis of haematologic indices in patients suffering from celiac disease.

The data presented above suggest a serious depletion in the transport and tissue pool of iron storage in children both with LID and IDA. The ferritin index in children with IDA is 5,9 times $(p<0.001)$, and in those with LID -2.4 times $(p<0.05)$ as low as in children with no ID. Interestingly, the iron level in serum, which in patients with IDA is 2.2 times $(p<0.001)$, and in those with LID is 2.0 times $(p<0.001)$ as low as in children with no ID, shows virtually no difference between patients with various types of ID ( $p>0.05)$. Yet, even children showing no

\section{References}

1. Belmer S. V., Semenova E. V., Smetanina N. S., Malkoch A. V. Haematologic manifestations of celiac disease. Celiac disease in children. M.: «Publishing House MEDPRACTICA-M»; 2013. P. 261-274.

2. Samsygina G. A., Kazyukova T. V., Levina A. A. Iron deficiency in children and adolescents: causes, diagnostics, treatment, prevention. M.: «Pirogova Russian State Medical University»; 2006. 32 p.

3. Zakharova I. N., Roslavtseva E. A., Borovik T. E. et al. Clinical variants of celiac disease in Pediatric practice. Issues of Diagnostics in Pediatrics. 2011;3(6):52-58.

4. Parfenov A. I. Celiac disease. Evolution of ideas on prevalence, clinical symptoms, and etiotropic therapy. M.: «Anaharsis»; 2007. 376 p.
Table 2

Haematologic features in children depending on the presence/absence of iron deficiency at the verification age for celiac disease

\begin{tabular}{|l|c|c|c|}
\hline \multirow{2}{*}{$\begin{array}{c}\text { Hemogram } \\
\text { test data }\end{array}$} & \multicolumn{3}{|c|}{ Patients with celiac disease } \\
\cline { 2 - 4 } & $\begin{array}{c}\text { IDA, } \\
\mathrm{n}=37\end{array}$ & $\begin{array}{c}\text { LID, } \\
\mathrm{n}=37\end{array}$ & $\begin{array}{c}\text { No ID, } \\
\mathrm{n}=52\end{array}$ \\
\hline $\begin{array}{l}\text { Haemoglobin } \\
(\mathrm{g} / \mathrm{l})\end{array}$ & $94.9 \pm 2.15$ & $125.0 \pm 1.51$ & $127.0 \pm 1.24$ \\
\hline $\begin{array}{l}\text { Erythrocytes } \\
\left(\mathrm{x} 10^{12} / \mathrm{l}\right)\end{array}$ & $3.8 \pm 0.12$ & $4.4 \pm 0.09$ & $4.4 \pm 0.06$ \\
\hline $\mathrm{MCV}(\mathrm{fl})$ & $78.2 \pm 2.6$ & $76.8 \pm 1.8$ & $78.1 \pm 1.1$ \\
\hline $\mathrm{MCH}(\mathrm{pg})$ & $26.3 \pm 0.8$ & $26.7 \pm 0.6$ & $27.4 \pm 0.4$ \\
\hline $\mathrm{MCHC}(\mathrm{g} / \mathrm{I})$ & $33.8 \pm 0.54$ & $34.8 \pm 0.26$ & $35.1 \pm 0.23$ \\
\hline $\mathrm{RDW}(\%)$ & $15.4 \pm 1.0$ & $13.5 \pm 0.8$ & $11.6 \pm 0.3$ \\
\hline $\begin{array}{l}\text { Iron serum } \\
\text { Concentration } \\
(\mu \mathrm{mol} / \mathrm{I})\end{array}$ & $6.8 \pm 0.62$ & $7.5 \pm 0.37$ & $14.9 \pm 0.39$ \\
\hline Ferritin $(\mu \mathrm{g} / \mathrm{l})$ & $7.5 \pm 1.7$ & $18.3 \pm 9.7$ & $44.4 \pm 8.4$ \\
\hline
\end{tabular}

laboratory data typical of ID, have their average iron concentration in the serum at the lowest normal threshold $(14 \mu \mathrm{mol} / \mathrm{I})$, which is another proof to the idea that sideropenic anemia is very typical of most patients with celiac disease, and it goes through a number of stages, the so-called pre-latent ID stage included $[1,7,10]$.

It is natural that along with progressing sideropenic anemia there come serious changes in the morphometric properties of erythrocytes, namely the RDW is growing, that being a reflection of the anisocytosis intensity, which, in children with LID is $16 \%(p<0.05)$, and in children with IDA is $33 \%(p<0.001)$ above the same index revealed in those that have no ID.

Conclusion. Inview ofall this, a highoccurrence of ID in children with celiac disease supports the stance that views sideropenic anemia as one of the earliestand most persistent symptoms of polyhypomicroelementosis, which is typical of this ailment, and mostly associated with body mass deficiency and the development of protein-calorie deficiency. The IDA rate proved to be high among children on their first year of life as well as in schoolers, which could be accounted for, in the former case, by a high need for iron, which does not match the morphofunctional characteristics of the intestinal mucosa, while in the latter case this could be due to a longer course of the illness together with an increasing depletion in the transport and tissue pool of iron storage.

5. Sabelnikova E. A., Parfenov A. I., Krums L. M. Celiac disease as a reason behind iron deficiency anemia. Ter. Archives. 2006;2:45-48.

6. Sanakoeva L. P., Diagnostics, treatment, and prevention of iron deficiency anemia in early childhood. Vagner PermGMA; $2011.44 \mathrm{p}$.

7. Semenova E. V., Belmer S. V., Kazanets E. G. et al. Anemia in case of celiac disease in children. Child Hospital. 2012;1:44-49.

8. Stoyan M. V., Kuryaninova V. A., Klimov L. Ya. et al. Occurrence and clinical-anamnestic features in children with iron deficiency through acute stage of celiac disease. Volume of XX Jubilee Congress for Child Gastroenterologists of Russia. M.: "Publishing House MEDPRACTICA-M»; 2013. P. 141-142. 
9. Bergamaschi G., Markopoulos K., Albertini R. et al. Anemia of chronic disease and defective erythropoietin production in patients with celiac disease. Haematologica. 2008;93:1785-1791.

10. Carroccio A., Iannitto E., Cavataio F. et al. Sideropenic anemia and celiac disease: one study, two points of view. Dig. Dis. Sci. 1998;43:673-678.

11. de Vizia B., Poggi V., Conenna R., Fiorillo A., Scippa L. Iron absorption and iron deficiency in infants. Pediatr. Gastroenterol. Nutr. 1992;14:21-26.

12. Fisgin T., Yarali N., Duru F. et al. Hematologic manifestation of childhood celiac disease. Acta Haematol. 2004;111:211-214.

\section{DURATION OF LATENT PERIOD AND IRON DEFICIENCY DEVELOPMENT IN CHILDREN WITH CELIAC DISEASE \\ KLIMOV L. Y., KURYANINOVA V. A., STOYAN M. V., ASATUROVA D. V., \\ GERASIMENKO E. S., DAGUZHIEVA M. D.}

An analysis of iron deficiency (ID) occurrence was conducted; this involved 126 children with celiac disease depending on the age and the duration of the ailment's latent period. The general occurrence rate of ID in children with celiac disease was $58.7 \%$, in those on their first year of life it was diagnosed in $90.0 \%$ of cases, while in preschoolers the rate went down to be on the up again in schoolers (up to $70.0 \%$ ). As for the nosological pattern of ID in infants and schoolers, there is prevailing iron deficiency anemia (IDA), while patients aged 1-7 years have latent iron deficiency (LID) prevalent in them. In children with celiac disease the occurrence of IDA in its mild form was $64.9 \%$, moderate $-32.4 \%$, severe $-2.7 \%$.

An increase in the latent period of undiagnosed celiac disease in children and adolescents comes along with progressing depletion in the transport and tissue pool of iron storage, as well as changing quantitative and morphometric features in erythrocytes, which results in a growing occurrence rate of the manifest type of ID - IDA.

Key words: celiac disease, children, anemia, iron deficiency
13. Halfdanarson T. R., Litzow M. R., Murray J. A. Hematologic manifestations of celiac disease. Blood. 2007;109:412-421.

14. Harper J. W., Holleran S. F., Ramakrishnan R. et al. Anemia in celiac disease is multifactorial in etiology. American Journal of Hematology. 2007;82:9961000

15. Husby S., Koletzko S., Kopronay-Szabo I. R. et al. ESPGHAN guidelines for the diagnosis of coeliac disease. J. Pediatr. Gastroenterol. Nutr. 2012;54(1):136-160.

\section{ЗАВИСИМОСТЬ МЕЖАУ АЛИТЕАЬНОСТЬЮ ААТЕНТНОГО ПЕРИОАА И РАЗВИТИЕМ АЕФИЦИТА ЖЕАЕЗА У АЕТЕЙ С ЦЕАИАКИЕЙ \\ ^. Я. КАИМОВ, В. А. КУРЬЯНИНОВА, \\ М. В. СТОЯН, А. В. АСАТУРОВА, \\ Е. С. ГЕРАСИМЕНКО, М. А. ААГУЖИЕВА}

Проведён анализ частоты дефицита железа (ДЖ) у 126 детей с целиакией в зависимости от возраста и длительности латентного периода заболевания. Общая частота ДЖ у детей с целиакией составила 58.7 \%, причём среди больных первого года жизни он диагностирован в $90.0 \%$, в преддошкольном и дошкольном возрастах - несколько сокращается, и повторно возрастает (до 70,0 \%) у детей школьного возраста. В структуре форм ДЖ у детей грудного и школьного возраста превалирует железодефицитная анемия (ЖДА), а у больных в возрасте от 1 до 7 лет - латентный дефицит железа. У детей с целиакией частота ЖДА лёгкой степени составила $64.9 \%$, средней степени - $32.4 \%$, тяжёлой степени - $2.7 \%$.

Увеличение длительности латентного периода недиагностированной целиакии у детей и подростков сопровождается прогрессирующим истощением запасов транспортного и тканевого пула железа, изменяются количественные и морфометрические параметры эритроцитов, в результате чего растёт частота манифестной формы ДЖ - ЖДА

Ключевые слова: целиакия, дети, анемия, дефицит железа 